\title{
Effect of Polar and non Polar Extract of Ferula assafoetida Dermanyssus gallinae in vivo and in vitro Conditions
}

\author{
Samere Ghavami ${ }^{1}$, Keramat Asasi ${ }^{1}$ and Mostafa Razavi ${ }^{2}$ \\ ${ }^{1}$ Avian Diseases Research Center, School of Veterinary Medicine, Shiraz University, Shiraz, Iran \\ ${ }^{2}$ Department of Pathobiology, School of Veterinary Medicine, Shiraz University, Shiraz, Iran \\ *Corresponding author's Email: asasi@shirazu.ac.ir; ORCID: 0000-0001-6180-4182
}

Received: 29 Jun. 2020

Accepted: 16 Aug. 2020

\begin{abstract}
Dermanyssus gallinae is one of the most common arthropods in layers that affects the quality and quantity of egg production. Although there are different synthetic compounds against this mite, but despite these compounds, drug resistance and the presence of these compounds and synthetic compounds in meat and eggs makes that the use of alternative methods, as well as increased use of herbal extracts and essential oils. In the present study, the N-Hexane and Ethanol extracts of Ferula assafoetida were used. GC-MS analysis revealed the constituents of the two extracts. The lethal properties of the extracts were determined by contact toxicity. In this field study, ethanolic extract of Ferula assafoetida was sprayed on laying hens that infected with red mite. The most available compounds of the Ethanol extract and N-hexan extract of Ferula assafoetida were Diethylpyridine and Aurapten respectively in this study. The LC50 of Ethanol extract of Ferula assafoetida was $16 \mu \mathrm{g} / \mathrm{cm}^{3}$ and in vitro study determined that ethanolic extract of Ferula assafoetida has been able to reduce the red mite population. This study indicated Ethanol extract of Ferula assafoetida could use as a substitute compound against red mite.
\end{abstract}

Key words: Polar and nonpolar extract, Ferula assafoetida, Red mite

\section{INTRODUCTION}

Dermanyssus gallinae (red mite) is one of the most important arthropods, especially in laying hens all over the world (Sparagano et al., 2013; Kim et al., 2016; Tabari et al., 2017; Kim et al., 2018) that affects the quality and quantity of egg production, irritation, anemia and, even in the case of severe contamination, causes the death of the bird (George et al., 2009; Spargano et al., 2013). D. gallinae plays an important role in the transmission of rickettsial, viral and bacterial pathogens and occasionally causes skin irritation in humans (George et al., 2009; Na et al., 2011; Spargano et al., 2013).

There are various chemical combinations including organophosphates, pyrethroids and carbamates to counteract this mite. The continuous applications of these compounds have increased the resistance to these compounds in this mite (Marangi et al., 2009; George et al., 2009; Tabari et al., 2015). In addition, the chemical residues of these compounds in meat, eggs and the environment are among the limitations of the use of these compounds (Dalton et al., 2001). Because of this, it increases the importance of using alternative methods such as extracts and essential oils of plants of Ferula assafoetida to control red mite. The acaricidal properties of many plant extracts and essential oil have been reported against D.gallinae (Kim et al., 2004, 2007; George et al., 2009; Tabari et al., 2015; Nechita et al., 2015; Masoumi et al., 2016; Kim et al., 2016, 2018)

The genus of Ferula belong to the family of Apiaceae that distributed the Mediterranean area and central Asia including Iran and Afghanistan (Bagheri et al., 2010). F. assafoetida is traditionally use for the treatment disease including parasitic disease (Iranshahi et al., 2011). The compounds of this plant are $40-46 \%$ resin, $25 \%$ gum, $10-17 \%$ volatile oil and $1.510 \%$ ash. The resin consist of ferulic acid esters, free ferulicacid ,umblliferone and coumarine (Iranshahi et al., 2011). The sesquiterpenes and sesquiterpene coumarins are the most compound of the genus Ferula (Pimenov et al., 1982). The essential oils of $F$. assafoetida are strong ovicides and larvicides of mosquitoes (Muturi et al., 2018). anthelmintic (Kakar et al., 2013; Upadhyay et al., 2017) antiprotozoal activity (El Deeb et al., 2012; Bafghi et al., 2014; Barati et al., 2014) 
are a characteristic of this plant The acaricidal activity of $F$. assafoetida has not been investigated against $D$. gallinae. The purpose of this study was to investigate the acaricidal activity of polar (Ethanol) and nonpolar (Nhexan) extracts of $F$. assafoetida on red mite under in vivo and in vitro conditions.

\section{MATERIALS AND METHODS}

\section{Mites source}

Between October 2018 and may 2019 D. gallinae samples were collected from a laying poultry farm in Amol, Iran. The mites were placed in dark containers under $25{ }^{\circ} \mathrm{C}$ and humidity of $55 \%$ transferred to the laboratory in Science and Technology Park of sari, Iran

\section{Essential oil extraction and GC-MS analysis}

The aerial parts of $F$. assafoetida were collected in Mashhad city, Iran and dried on $25^{\circ} \mathrm{C}$. The aerial parts of $F$. assafoetida were ground mechanically using a commercialelectric mill. To provide Extract mill plant was macerated with ethanol and N-hexan in soxhlet apparatus and subsequently, the extract was filtered and solvent was evaporated by using a rotary evaporator and the acquired extract was dried in desiccator (Sonar et al., 2016). The polar extract was obtained by Ethanol solvent. However, the non-polar extract was obtained by $\mathrm{N}$-hexan solvent. To analyze and identify the constituents of the extract Gas chromatography coupled to mass spectrometry (model Shimadzu-QP5050A, Japan) was used. In this study, gas chromatography Agilent-6890 model equipped with DB-5 column with a length of $40 \mathrm{~m}$, an inner diameter of 0.18 $\mathrm{mm}$ to $0.25 \mathrm{~mm}$ thick layer of stationary phase are used. The column heat program was adjusted from 60 to $210{ }^{\circ} \mathrm{C}$ with a gradient of $5{ }^{\circ} \mathrm{C} / \mathrm{min}$. The injection chamber temperature was $280^{\circ} \mathrm{C}$ and the used detector temperature was $270{ }^{\circ} \mathrm{C}$. Helium gas was used as carrier gas and its speed was $0.9 \mathrm{~mm} / \mathrm{min}$ and fission ratio of 1 to 43 . The injection rate was $0.1 \mu 1$ of sample and the source ionization temperature was $230{ }^{\circ} \mathrm{C}$. The electron ionizatin mode and the ionization energy were $70 \mathrm{ev}$. A series of normal alkanes were also injected under the same conditions to calculate the retention index inhibition index. The sample retention index was calculated using a computer program.

Finally, the essential oil components were identified by comparing the mass spectra obtained with the standard mass spectra in the Wiley 2000 electronic library in Labsolution GC/MS software and computing the standard inhibition index and comparing them with the standard numbers in the references (Shibamoto, 1987; Adams, 2001).

\section{Contact toxicity}

Contact toxicity assay was done according to the method described by Tabari et al. (2015). In this study, treatment groups, control group of solvents, negative control and standard group were considered. 50 mites were added to all studied groups. The number of dead mites were recorded during 24, 48 and 72 hours after spraying the extract, and then the concentration of Lethal Concentration 50 (LC50) were calculated. Two replicates were carried out for all tested groups of mite.

\section{Experimental groups}

In the studied groups, the different concentrations were prepared $\left(0.5,1,2,4,8,16,32,64,128 \mu \mathrm{g} / \mathrm{cm}^{3}\right)$. For dilution of polar extract from Ethanol and for nonpolar extract of $\mathrm{N}$ - hexane solvent used. Polar extract diluted in $50 \mu 1$ Ethanol and non polar extract diluted in $50 \mu 1 \mathrm{~N}$ hexane, the Wattemn's paper was then embedded with dilutions after three minutes, the paper dried and the paper was loaded on to the plate, about 50 mites were added to each plate. The number of red mite that were lost during 24, 48, and 72 hours after treatment were counted. Negative control group without any treatment was placed with 50 red mites on filter papers at the bottom of the plate. In Ethanol solvent control group, the filter paper was smeared with $50 \mu \mathrm{l}$ of ethanol solvent and after two minutes, the filter paper was dried and placed on the bottom of the plate and then 50 red mites added to the plate. In N-hexan solvent control group, the filter paper was smeared with $50 \mu \mathrm{l}$ of N-hexan solvent and after 2 minutes, the filter paper was dried and placed on the bottom of the plate and then 50 red mites added to the plate. In standard group, the filter paper impregnated with $50 \mu \mathrm{l}$ of diluted cypermethrin solution and then dried at the bottom of the plate, about 50 red mites were added to the plate.

\section{In vitro experiment}

\section{Preparation nest}

The research was conducted in one of the laying farms of Amol city in may 2019. Each study group contained 20 laying hens (at 40 weeks of age) that reared in cage system (5 laying hens in each cage). Ventilation, lighting and temperature controlled on the basis of breed recommendations (LSL catalog, 2018). 


\section{Treatments}

In the treatment groups, the ethanolic extracts of $F$. assafoetida was sprayed on 20 LSL laying hens at 40 weeks of age based on the LC50 concentration obtained in vivo studies. The negative control group (without conflict with the red mite and untreated), positive control group (involved with the red mite untreated), standard (involved with red mite and treatment with Cypermethrin Mahan Chemical Company) was considered. Two replicates were considered for all study groups. In order to create red mite contamination, contaminated fields were collected from laying farm of Amol city, Iran and then in each group about 2000 experimental red mite were generated. According to the LC50 concentration indicated in the in vivo studies, Ethanolic extract of $F$. assafoetida and cypermethrin toxin were sprayed on the bird's body and repeated for one week more. 24 hours after each spray, the number of dead mites on the floor of each cage was measured and counted using adhesive paper traps.

\section{Statistical analysis}

The mortality rates of mites were analyzed using a one-way ANOVA in SPSS software (version 16). Values of $\mathrm{P} \leq 0.05$ were considered significant.

\section{RESULTS}

\section{GC-MS analysis}

The major constituents of the extract are shown in tables 1 and 2. The most available compounds in Ethanol extract were Diethylpyridine (23.54\%), Aurapten $(15.58 \%)$, Coumarin $(5.11 \%)$ respectively and N-hexan extract of Ferula assafoetida were Aurapten (16.39\%), Lutidine (7.36\%) and Ergosten (4.87) respectively.

Table 1. The constituents of Ethanolic extract of Ferula assafoetida

\begin{tabular}{lcc}
\hline Compound & Retention index & Peak area \\
\hline Coumarin & 41.65 & 5.11 \\
Quinolinium & 48.37 & 1.68 \\
Benzene & 48.76 & 1.96 \\
Ethylene & 48.98 & 2.1 \\
Methoxyindole & 49.82 & 7.19 \\
Phenol & 50.11 & 2.37 \\
Naphthalenone & 50.33 & 3.1 \\
Benzopyran & 50.62 & 2.93 \\
Aurapten & 51.16 & 15.58 \\
Diethylpyridine & 51.63 & 23.54 \\
Costol & 52.48 & 2.63 \\
Lavandulol & 53.92 & 3.72 \\
\hline
\end{tabular}

Table 2. The constituents of N-hexan extract of Ferula assafoetida

\begin{tabular}{lcc}
\hline Compound & $\begin{array}{c}\text { Retention } \\
\text { index }\end{array}$ & Peak area \\
\hline Geranyl & 33.467 & 3.62 \\
a.-Selinene & 33.99 & 3.78 \\
Farnesal & 34.81 & 1.07 \\
Myristoleate & 36.9 & 1.2 \\
Oleic acid & 37.03 & 1.85 \\
Decanone & 39.4 & 1.56 \\
Farnesol & 41.89 & 1.17 \\
Phenyl ethanone & 47.45 & 1.89 \\
Oelsauere & 48.15 & 2.06 \\
Dehydrogingerdione & 48.33 & 1.84 \\
Formamide & 48.83 & 1.27 \\
Isothiocyanate & 49 & 3.69 \\
Trienoic acid & 49.54 & 1.97 \\
Dimethoxyindole & 49.76 & 3.04 \\
Benzenedicarboxylic acid & 50.12 & 2.7 \\
Xanthene & 50.42 & 2.9 \\
Aurapten & 51.35 & 16.39 \\
Lutidine & 51.7 & 7.36 \\
Ergosten & 52.89 & 4.87 \\
Quinoline & 53.21 & 3.91 \\
Squalene & 55.91 & 1.32 \\
\hline
\end{tabular}

\section{Contact toxicity}

Generally in all studied timings (After 24 hours, 48 hours and 72 hours), the results indicated that the responses to treatments were the extraction method and dose dependent in contact toxicity assay, Ethanol extracts of Ferula assafoetida was effective than N-hexan extract on red mite $(\mathrm{P} \leq 0.05)$. The LC50 was $16 \mu \mathrm{g} / \mathrm{cm}^{3}$ for Ethanol extracts (Table 3).

\section{In vitro study}

The ethanolic extract of $F$. assafoetida was effective on red mite under field conditions and the differences between groups were significant $(\mathrm{P} \leq 0.05)$. After first spray, the number of dead red mite was not significant between positive and negative control $(\mathrm{P}>0.05)$ but mean mortality rates of mites in treatment group with F.assafoetida extract and standard groups significantly higher than the control groups $(\mathrm{P} \leq 0.05)$. After the second spray, the number of dead red mites in treatment group with $F$. assafotida and standard group were significantly higher than the control groups ( $\mathrm{P} \leq 0.05$, Table 4$)$. 
Ghavami et al., 2020

Table 3. Comparison of lethal effect polar and nonpolar extracts of Ferula assafoetida on red mite at different times

\begin{tabular}{|c|c|c|c|c|}
\hline Treatment & After 24 hours & After 48 hours & After 72 hours & Total \\
\hline $\begin{array}{l}\text { N-hexan } F \text {. assafoetida } \\
128 \mu \mathrm{g} / \mathrm{cm}^{3}\end{array}$ & $1^{\mathrm{a}}$ & $1.33 \pm 0.33^{\mathrm{a}}$ & $1.33 \pm 0.33^{\mathrm{a}}$ & $1.22 \pm 0.14^{\mathrm{a}}$ \\
\hline $\begin{array}{l}\text { N-hexan } F \text {. assafoetida } \\
64 \mu \mathrm{g} / \mathrm{cm}^{3}\end{array}$ & $0^{\mathrm{a}}$ & $0.33 \pm 0.33^{\mathrm{a}}$ & $0.33 \pm 0.33^{\mathrm{a}}$ & $0.22 \pm 0.14^{\mathrm{a}}$ \\
\hline $\begin{array}{l}\text { N-hexan } F \text {. assafoetida } \\
32 \mu \mathrm{g} / \mathrm{cm}^{3}\end{array}$ & $0.33 \pm 0.33^{\mathrm{a}}$ & $0.33 \pm 0.33^{\mathrm{a}}$ & $0.33 \pm 0.33^{\mathrm{a}}$ & $0.33 \pm 0.16^{\mathrm{a}}$ \\
\hline $\begin{array}{l}\text { N-hexan } F \text {. assafoetida } \\
16 \mu \mathrm{g} / \mathrm{cm}^{3}\end{array}$ & $0^{\mathrm{a}}$ & $0.33 \pm 0.33^{\mathrm{a}}$ & $0.33 \pm 0.33^{\mathrm{a}}$ & $0.22 \pm 0.14^{\mathrm{a}}$ \\
\hline $\begin{array}{l}\text { N-hexan } F . \text { assafoetida } \\
8 \mu \mathrm{g} / \mathrm{cm}^{3}\end{array}$ & $1 \pm 0.57^{\mathrm{a}}$ & $1 \pm 0.57^{\mathrm{a}}$ & $1 \pm 0.57^{\mathrm{a}}$ & $1 \pm 0.28^{\mathrm{a}}$ \\
\hline $\begin{array}{l}\text { N-hexan } F . \text { assafoetida } \\
4 \mu \mathrm{g} / \mathrm{cm}^{3}\end{array}$ & $1^{\mathrm{a}}$ & $1^{\mathrm{a}}$ & $1^{\mathrm{a}}$ & $1^{\mathrm{a}}$ \\
\hline $\begin{array}{l}\text { N-hexan } F \text {. assafoetida } \\
2 \mu \mathrm{g} / \mathrm{cm}^{3}\end{array}$ & $0^{\mathrm{a}}$ & $0^{\mathrm{a}}$ & $0^{\mathrm{a}}$ & $0^{\mathrm{a}}$ \\
\hline $\begin{array}{l}\text { N-hexan F. assafoetida } \\
1 \mu \mathrm{g} / \mathrm{cm}^{3}\end{array}$ & $0.66 \pm 0.33^{\mathrm{a}}$ & $0.66 \pm 0.33^{\mathrm{a}}$ & $0.66 \pm 0.33^{\mathrm{a}}$ & $0.66 \pm 0.16^{\mathrm{a}}$ \\
\hline $\begin{array}{l}\text { N-hexan F.assafoetidaa } \\
0.5 \mu \mathrm{g} / \mathrm{cm}^{3}\end{array}$ & $0^{\mathrm{a}}$ & $0^{\mathrm{a}}$ & $0^{\mathrm{a}}$ & $0^{\mathrm{a}}$ \\
\hline $\begin{array}{l}\text { Ethanol } F . \text { assafoetida } \\
128 \mu \mathrm{g} / \mathrm{cm}^{3}\end{array}$ & $41 \pm 0.57^{\mathrm{f}}$ & $41.33 \pm 0.66^{\mathrm{f}}$ & $41.33 \pm 0.66^{\mathrm{f}}$ & $41.22 \pm 0.32^{\mathrm{g}}$ \\
\hline $\begin{array}{l}\text { Ethanol } F \text {. assafoetida } \\
64 \mu \mathrm{g} / \mathrm{cm}^{3}\end{array}$ & $35^{\mathrm{e}}$ & $41 \pm 0.57^{\mathrm{f}}$ & $41 \pm 0.57^{\mathrm{f}}$ & $39 \pm 1^{g}$ \\
\hline $\begin{array}{l}\text { Ethanol F. assafoetida } \\
32 \mu \mathrm{g} / \mathrm{cm}^{3}\end{array}$ & $25 \pm 0.57^{\mathrm{d}}$ & $33.33 \pm 1.6^{\mathrm{e}}$ & $33.33 \pm 1.6^{\mathrm{e}}$ & $30.55 \pm 1.55^{\mathrm{f}}$ \\
\hline $\begin{array}{l}\text { Ethanol } F \text {. assafoetida } \\
16 \mu \mathrm{g} / \mathrm{cm}^{3}\end{array}$ & $16.66 \pm 1.66^{\mathrm{c}}$ & $24.66 \pm 0.88^{\mathrm{d}}$ & $24.66 \pm 0.88^{\mathrm{d}}$ & $22 \pm 1.46^{\mathrm{d}}$ \\
\hline $\begin{array}{l}\text { Ethanol F. assafoetida } \\
8 \mu \mathrm{g} / \mathrm{cm}^{3}\end{array}$ & $8.33 \pm 1.66^{\mathrm{b}}$ & $17.66 \pm 1.45^{\mathrm{c}}$ & $17.66 \pm 1.45^{\mathrm{c}}$ & $14.55 \pm 1.73^{\mathrm{c}}$ \\
\hline $\begin{array}{l}\text { Ethanol } F \text {. assafoetida } \\
4 \mu \mathrm{g} / \mathrm{cm}^{3}\end{array}$ & $3.33 \pm 1.66^{\mathrm{a}}$ & $10^{\mathrm{b}}$ & $10.33 \pm 0.33^{b}$ & $7.88 \pm 1.24^{\mathrm{b}}$ \\
\hline $\begin{array}{l}\text { Ethanol F. assafoetida } \\
2 \mu \mathrm{g} / \mathrm{cm}^{3}\end{array}$ & $0.33 \pm 0.33^{\mathrm{a}}$ & $0.33 \pm 0.33^{\mathrm{a}}$ & $0.66 \pm 0.33^{\mathrm{a}}$ & $0.44 \pm 0.24^{\mathrm{a}}$ \\
\hline $\begin{array}{l}\text { Ethanol F. assafoetida } \\
1 \mu \mathrm{g} / \mathrm{cm}^{3}\end{array}$ & $0^{\mathrm{a}}$ & $1^{\mathrm{a}}$ & $1^{\mathrm{a}}$ & $0.66 \pm 0.16^{\mathrm{a}}$ \\
\hline $\begin{array}{l}\text { Ethanol } F \text {. assafoetida } \\
0.5 \mu \mathrm{g} / \mathrm{cm}^{3}\end{array}$ & $0^{\mathrm{a}}$ & $0.33 \pm 0.33^{\mathrm{a}}$ & $0.33 \pm 0.33^{\mathrm{a}}$ & $0.22 \pm 0.14^{\mathrm{a}}$ \\
\hline Standard & $45.33 \pm 0.33^{\mathrm{g}}$ & $46.33 \pm 0.33^{\mathrm{a}}$ & $46.33 \pm 0.33^{\mathrm{a}}$ & $46.11 \pm 0.26^{\mathrm{h}}$ \\
\hline N-hexan control & $1 \pm 0.57^{\mathrm{a}}$ & $2^{\mathrm{a}}$ & $2^{\mathrm{a}}$ & $1.66 \pm 0.23^{\mathrm{a}}$ \\
\hline Ethanol control & $0.33 \pm 0.33^{\mathrm{a}}$ & $2^{\mathrm{a}}$ & $2^{\mathrm{a}}$ & $1.44 \pm 0.29^{\mathrm{a}}$ \\
\hline Pasitive control & $0.33 \pm 0.33^{\mathrm{a}}$ & $1.66 \pm 0.33^{\mathrm{a}}$ & $2^{\mathrm{a}}$ & $1.33 \pm 0.28^{\mathrm{a}}$ \\
\hline
\end{tabular}

Non-anonymous latin letters in each column indicate significant difference $(\mathrm{P} \leq 0.05)$.

Table 4. Comparison of lethality of ethanolic extract of Ferula assafoetida on red mite under field conditions

\begin{tabular}{lcc}
\hline Treatment & $\begin{array}{c}\text { Number of dead red mite after } \\
\text { first spray }\end{array}$ & $\begin{array}{c}\text { Number of dead red mite after } \\
\text { second spray }\end{array}$ \\
\hline Ethanolic Extract of $F$. assafoetida & $30 \pm 2.3^{\mathrm{b}}$ & $40 \pm 1.52^{\mathrm{c}}$ \\
Standard & $60 \pm 3.46^{\mathrm{c}}$ & $50 \pm 1.15^{\mathrm{d}}$ \\
Negative control & $0^{\mathrm{a}}$ & $0^{\mathrm{a}}$ \\
Positive control & $5 \pm 1.15^{\mathrm{a}}$ & $7 \pm 0.57^{\mathrm{b}}$ \\
\hline
\end{tabular}

Non-anonymous Latin letters in each column indicates significant difference $(\mathrm{P} \leq 0.05)$ 


\section{DISCUSSION}

F. assafoetida is a well-known traditional plant with antiparasitc properties. Anti-parasitic activity of this plant against leishmania (Bafghi et al. 2014, Gholami et al. 2013), cestode (Farhadi et al. 2016) culex (Muturi et al. 2018) Giardia (Nazer et al., 2019) and mosquito (Evergetis et al., 2012) has been demonstrated. Despite there are extensive reports concerning excellent insecticidal activity af $F$. asafoetida, there was no study to evaluate its acaricidal activity on D. gallinae. The present study is one the first in vitro and in vivo acaricidal studies of $F$. assafoetida against $D$. gallinae. In present study it was obtained that ethanolic extract was effective on $D$. gallinae in vitro and in vivo but $\mathrm{N}-\mathrm{Hexan}$ extract had no significant effect on $D$. gallinae. This could be due to such active compounds in the ethanolic extract of $F$. assafoetidae.

The GC-MS analyses indicated that Ethanolic extract of $F$. assafoetidae was Diethylpyridine $(23.54 \%)$ but NHexan extract of $F$. assafoetidae was Aurapten (16.39\%). The anti parasitic effect of Diethylpyridine has been demonstrated against leshmania (Abdala et al., 2002). Generally, the major components of plant materials play the main role to determine the biological properties, but this point should not be ignored that the potential of the major compositions may be regulated by other minor components and the biological activites of plant materials are on account of synergistic/antagonistic interactions of all constitutes (Szcepanik et al., 2012).

El-Razek et al. (2001) and Pimenov et al. (1982) and Iranshahi et al. (2012) have reported that the most constituent compounds of $F$. assafoetida are sesquiterpenes and sesquiterpene coumarins. Numerous factors like geographic origin, seasonality, method of oil extraction, year of harvest and even storage conditions could affect the composition of essential oils, so the results from different toxicity studies might not always be adequate (Chalchat et al., 2007).

According to the present study ethanolic extract of $F$. assafoetidae was effective on red mite and LC50 was obtained $16 \mu \mathrm{g} / \mathrm{cm}^{3}$. However $\mathrm{N}$-Hexan extract of $F$. assafoetidae was not effective on red mite. In a similar study the aquatic and ethanolic extracts of Conocarpus erectus, regarding relative toxic and repellency properties, were used as botanical, safe acaricide and repellent agent for control of D. gallinae in avicultures (Rajabpour et al., 2018). The similar results were reported about Ethanol extract of Syzygium cumini and indicated the most efficient acaricidal activity against Tetranychus urticae followed by hexane extract, ether and ethyl acetate extracts (Afify et al., 2011). The similar studies reported Ethanolic extracts of Veratrum album and Tanacetum parthenium could be useful to control Tetranychus urticae populations on vegetable plants grown through Integrated Pest Management and organic systems of agriculture (Yildirim et al., 2012).

Present results shows the ethanol extract of $F$. assafoetidae was effective on red mite in vitro condition. Some studies reported that the neem seed extract acaricide has positive against red mite in vitro coundition (Abdelghafar et al. 2008; Locher et al., 2010). Similar findings were reported on garlic (Allium sativum) extract for controlling red mite infestation in a layer farm in Babol, North of Iran (Faghihzade et al., 2014).

\section{CONCLUSION}

Present findings indicated that the ethanolic extract of Ferula assafoetidae was effective on red mite and reduced the red mite population in vivo and in vitro condition but N-Hexan extract of Ferula assafoetidae was not effective on red mite, due to active components like Diethylpyridine and LC50 of ethanolic extract that was indicated 16 $\mu \mathrm{g} / \mathrm{cm} 3$.

\section{REFERENCES}

Abdel-Ghaffar F, Sobhy HM, Al-Quraishy S and Semmler M (2008). Field study on the efficacy of an extract of neem seed (MiteStop®)against the red mite Dermanyssus gallinae naturally infecting poultry in Egypt. Parasitology Research, 103(3):481-485. DOI: http://www.doi.org/10.1007/s00436-008-0965-9.

Adams RP (2001). Identification of Essential oil Components by Gas Chromatography/Quadropole Mass Spectroscopy Carol Stream IL: Allured Publishing Crop, P.465. Available at: https://lib.ugent.be/en/catalog/rug01:000800424.

Bafghi AF, Bagheri SM and Hejazian SH (2014). Antileishmanial activity of Ferula assafoetida oleo gum resin against Leishmania major: An in vitro study. Journal of Ayurveda and Integrative Medicine, 5: 223-226. DOI: http://www.doi.org/ 10.4103/09759476.146567

Barati M, Sharifi I, Sharififar F, Parizi MH and Shokri A (2014). Antileishmanial activity of Gossypium hirsutum L., Ferula assafoetida L. and Artemisia aucheri Boiss. Extracts by colorimetric assay. Anti-Infective Agents, 12: 159-164. DOI: http://www.doi.org/10.2174/22113525113119990005.

Chalchat JC, Ozcan MM, Dagdelen A and Akgul A (2007). Variability of essential oil composition of Echinophora tenuifolia subsp. Sibthorpiana Tutin by harvest location and year and oil storage. Chemistry of Natural Compounds, 43:225-227. DOI: http://www.doi.org/10.1007/s10600-007-0087-0.

Dalton JP and Mulcahy G (2001). "Parasite vaccines-a reality?" Veterinary Parasitology, 98: 149-167. DOI: http://www.doi.org/ 10.1016/s0304-4017(01)00430-7. 
Fiddes MD, Le Gresley S, Parsons DG, Epe C, Coles GC and Stafford KA (2005). "Prevalence of the poultry red mite (Dermanyssus gallinae) in England".Veterinary Record, 157:233-235.DOI: http://www.doi.org/10.1136/vr.157.8.233 .

EvergetisE, Michaelakis A and Haroutounian SA (2012). Essential oils of Umbelliferae (Apiaceae) family taxa as emerging potent agents for mosquito control. Integrated Pest Management and Pest Control - Current and Future Tactics: Intech Publication. DOI: http://www.doi.org/10.5772/31777.

Faghihzadeh Gorji S, Faghihzadeh Gorji S and Rajabloo M (2014). The field efficacy of garlic extract against Dermanyssus gallinae in layer farms of Babol, Iran. Parasitology Research, 113:1209-13. DOI: http://www.doi.org/10.1007/s00436-014-3759-2.

Farhadi A, Youssefi M and Tabari M (2016). Evaluation of the anticestode and antinematode effects of the methanol extract of Ferula asafoetida on experimentally infected rats. Journal of Babol University of Medical Sciences,18(6):47-51. Available at: http://www.jbums.org/browse.php?a_id=5809\&sid=1\&slc_lang=en

George DR, Smith TJ, Shiel RS, Sparagano OAE and Guy JH (2009). Mode of action and variability in efficacy of plant essential oils showing toxicity against the poultry red mite, Dermanyssus gallinae.Veterinary Parasitology, 161: 276-282. DOI: http://www.doi.org/10.1016/j.vetpar.2009.01.010.

Gholami AR, Khamesipour A, Momeni A, Ghazanfari T, Nilforoushzadeh MA and Darajeh Z (2000). Treatment of cutaneous leishmaniasis with 5\% garlic cream: A randomized, double-blind study. Iran J Dermatology,3(11):2-6. Available at: http://www.iranjd.ir/article_98383.html.

Iranshahi M (2012). A review of volatile sulfur containing compounds from terrestrial plants: Biosynthesis, distribution and analytical methods. Journal of Essential Oil Research, 24:393-434. DOI: https://www.doi.org/10.1080/10412905.2012.692918.

Kakar SA, Tareen RB, Sandhu ZUD, Azam Kakar M, Kakar SUR, Iqbal $\mathrm{Z}$ and Jabeen $\mathrm{H}$ (2013). In vitro and in vivo anthelmintic activity of Ferula costata (Kor.) against gastrointestinal nematodes of sheep. Available at: Pakistan Journal of Botany, 45: 263-268.

Kim S, Yi J, Tak J and Ahn Y (2004). Acaricidal activity of plant essential oils against Dermanyssus gallinae (Acari: Dermanyssidae). Veterinary Parasitology, 120: 297-304. DOI: http://www.doi.org/ 10.1016/j.vetpar.2003.12.016.

Kim S, Na YE, Yi JH, Kim BS and Ahn YJ (2007). Contact and fumigant toxicity of oriental medicinal plant extracts against Dermanyssus gallinae (Acari: Dermanyssidae). Veterinary Parasitology, 145: 377-382. DOI: http://www.doi.org/10.1016/j.vetpar.2006.12.021.

Kirkwood AC (1968). Anemia in poultry infested with red mite Dermanyssus gallinae. Veterinary Record, 80:514-516. DOI: http://www.doi.org/10.1136/vr.80.17.514.

Kim JR, Perumalsamy H, Lee JH, Ahn YJ, Lee YS and Lee SG (2016). Acaricidal activity of Asarum heterotropoidesroot-derived compounds and hydrodistillate constitutes toward Dermanyssus gallinae (Mesostigmata: Dermanyssidae). Experimental and Applied Acarology, 68 (4): 485-495. DOI: http://www.doi.org/ 10.1007/s10493-015-0005-2.

Kim HK, Lee SJ, Hwang BY, Yoon JU and Kim GH (2018). Acaricidal and repellent effects of Cnidium officinale-derived material against Dermanyssus gallinae (Acari:Dermanyssidae). Experimental and Applied Acarology, 74 (4): 403-414. DOI: http://www.doi.org/ 10.1007/s10493-018-0249-8.

Locher N, Al-Rasheid Kh AS, Abdel-Ghaffar F and Mehlhorn H (2010). In vitro and field studies on the contact and fumigant toxicity of a neem-product (Mite-Stop ${ }^{\circledR}$ ) against the developmental stages of the poultry red mite Dermanyssus gallinae. Parasitology Research, 107:417-423. DOI: http://www.doi.org/10.1007/s00436-010-18822.
Masoumi F, Youssefi MR and Tabari MA (2016). Combination of carvacrol and thymol against the poultry red mite (Dermanyssus gallinae). Parasitology Research, 115:4239-4243. DOI: http://www.doi.org/10.1007/s00436-016-5201-4.

Marangi M, Cafiero MA, Capelli G, Camarda A, Sparagano OAE and Giangaspero A (2009). Evaluation of the poultry red mite, Dermanyssus gallinae (Acari: Dermanyssidae) susceptability to some acaricides in field populations from Italy. Experimental and Applied Acarology, 48:11-8. DOI: http://www.doi.org/ 10.1007/s10493-008-9224-0.

Muturi EJ, Ramirez JL, Zilkowski B, Flor-Weiler LB and Rooney AP (2018). Ovicidal and larvicidal effects of garlic and assafoetida essential oils against west nile virus vectors. Journal of Insect Science, 18: 43-49. DOI: http://www.doi.org/ 10.1093/jisesa/iey036.

Na YE, Kim SI, Bang HS, Kim BS and Ahn YJ (2011). Fumigant toxicity of cassia and cinnamon oils and cinnamaldehyde and structurally related compounds to Dermanyssus gallinae (Acari: Dermanyssidae). Veterinary Parasitology, 178 (3-4): 324-329. DOI: http://www.doi.org/ 10.1016/j.vetpar.2011.01.034.

Nazer R, Abbaszadeh S, Anbari K and Shams M (2019). A review of the most important medicinal herbs affecting giardiasis. Journal of Herbmed PharmacologyJ Herbmed Pharmacol, 8(2): 78-84. DOI: http://www.doi.org/ 10.15171/jhp.2019.13.

Nechita I, Poirel M, Cozma V and Zenner L ( 2015). The repellent and persistent toxic effects of essential oils against the poultry red mite, Dermanyssus gallinae. Veterinary Parasitology, 214 (3-4): 348352. DOI: http://www.doi.org/10.1016/j.vetpar.2015.10.014.

Pimenov MG, Sklyar YE, Savina A and Baranova YV (1982). Chemosystematics of section Palaeonarthex of the genus Ferula. Biochemical Systematics and Ecology, 10: 133-138. DOI: http://www.doi.org/10.1016/0305-1978(82)90019-9

Prakash AO and Pathak SR (1991). Postcoital contraceptive action in rats of a hexane extract of the aerial parts of Ferula jaeschkeana. Journal of Ethnopharmacology, 34(2): 221-234. DOI: http://www.doi.org/10.1016/0378-8741(91)90041-B.

Shibamoto T (1987). Retention Indices in Essential Oil Analysis. In: Capillary Gas Chromatography in Essential Oil Analysis, Sandra, P. and C. Bicchi (Eds.). Huethig-Verlag, New York, USA., pp. 259274.

Sonar PK, Singh R and Saraf SK (2016). Phytochemical, chromatographic and spectroscopic investigation of Carum copticum seeds and their potential as immunomodulatory agents. Pharmaceutical Biology. 54 (3): 494-502. DOI: http://www.doi.org/ 10.3109/13880209.2015.1050116.

Sparagano O, Khallaayoune K, Duvallet G, Nayak S and George D (2013). Comparing terpenes from plant essential oils as pesticides for the poultry red mite (Dermanyssus gallinae). Transboundary and Emerging Diseases, 60 (2): 150-153. DOI: http://www.doi.org/10.1111/tbed.12138.

Szczepanik M, Zawitowska B and Szumny A ( 2012). Insecticidal activities of Thymus vulgaris essential oil and its components (thymol and carvacrol) against larvae of lesser mealworm, Alphitobius diaperinus Panzer (Coleoptera: Tenebrionidae). Allelopathy Journal , 30 (1): 129-142.

Tabari MA, Youssefi MR, Barimani A and Araghi A (2015). Carvacrol as a potent natural acaricide against Dermanyssus gallinae. Parasitology Research, 114:3801-3806. DOI: http://www.doi.org/10.1007/s00436-015-4610-0

Tabari M, Youssefi MR and Benelli G (2017). Eco-friendly control of the poultry red mite, Dermanyssus gallinae (Dermanyssidae), using the $\alpha$ thujone-rich essential oil of Artemisia sieberi (Asteraceae): toxic and repellent potential Parasitology Research, 116:1545-1551. DOI: https:// www.doi.org/10.1007/s00436-017-5431-0 
Upadhyay PK, Singh S, Agrawal G and Vishwakarma VK (2017). Pharmacological activities and therapeutic uses of resins obtained from Ferula assafoetida Linn.: a review. International Journal of $\begin{array}{lccc}\text { Green Pharmacy, } & \text { 11: } & \text { S247. } & \text { DOI: } \\ \text { https://www.doi.org/10.22377/JGP.V11I02.1033 } & \end{array}$ 